\title{
BMJ Global Health Advancing Planetary Health in Australia: focus on emerging infections and antimicrobial resistance
}

\author{
Grant Hill-Cawthorne, ${ }^{1,2}$ Joel Negin, ${ }^{2}$ Tony Capon, ${ }^{2}$ Gwendolyn L Gilbert, ${ }^{1}$ \\ Lee Nind, ${ }^{3}$ Michael Nunn, ${ }^{4}$ Patricia Ridgway, ${ }^{5}$ Mark Schipp, ${ }^{3}$ Jenny Firman, ${ }^{6}$ \\ Tania C Sorrell, ${ }^{1}$ Ben J Marais ${ }^{\bullet 1}$
}

To cite: Hill-Cawthorne G, Negin J, Capon T, et al. Advancing Planetary Health in Australia: focus on emerging infections and antimicrobial resistance. BMJ Glob Health 2019;4:e001283. doi:10.1136/ bmjgh-2018-001283

Handling editor Seye Abimbola

Received 6 November 2018 Revised 19 February 2019 Accepted 25 February 2019

\section{Check for updates}

(c) Author(s) (or their employer(s)) 2019. Re-use permitted under CC BY-NC. No commercial re-use. See rights and permissions. Published by BMJ.

For numbered affiliations see end of article.

Correspondence to Professor Ben J Marais; ben.marais@health.nsw.gov.au

\section{ABSTRACT}

With rising population numbers, anthropogenic changes to our environment and unprecedented global connectivity, the World Economic Forum ranks the spread of infectious diseases second only to water crises in terms of potential global impact. Addressing the diverse challenges to human health and well-being in the 21st century requires an overarching focus on 'Planetary Health', with input from all sectors of government, non-governmental organisations, academic institutions and industry. To clarify and advance the Planetary Health agenda within Australia, specifically in relation to emerging infectious diseases (EID) and antimicrobial resistance (AMR), national experts and key stakeholders were invited to a facilitated workshop. EID themes identified included animal reservoirs, targeted surveillance, mechanisms of emergence and the role of unrecognised human vectors (the 'invisible man') in the spread of infection. Themes related to AMR included antimicrobial use in production and companion animals, antimicrobial stewardship, novel treatment approaches and education of professionals, politicians and the general public. Effective infection control strategies are important in both EID and AMR. We provide an overview of key discussion points, as well as important barriers identified and solutions proposed.

\section{INTRODUCTION}

The 21st century confronts us with profound global challenges such as food, water and energy security, reduced resilience of our planet's life-giving ecosystems and threats from emerging and antimicrobial-resistant infections. According to the World Economic Forum, the spread of infectious diseases is now ranked second only to water crises as the global risk with the greatest likelihood and potential impact, ${ }^{1}$ while the One World One Health concept recognises that human and animal health are intimately linked and ultimately dependent on healthy ecosystems. ${ }^{23}$ In 2015, The Rockefeller Foundation invested US $\$ 15$ million to establish the pillars of a new discipline called Planetary Health,

\section{Summary box}

- The emergence and spread of infectious diseases, including antimicrobial-resistant infections, pose a major health security threat.

- A more holistic approach to emerging infectious diseases (EID) and antimicrobial resistance (AMR) is essential to encourage 'resilience thinking'

- Within Australia, the National Framework for Communicable Disease Control and National Antimicrobial Resistance Strategy encourage a coordinated One Health approach, but implementation remains challenging

- Methodologies for better decision-making during infectious disease outbreaks require refinement, especially detailed scenario planning and improved communication during times of uncertainty.

- Breaking down traditional medical, veterinary and biological research silos is crucial, with dedicated funding to support cross-disciplinary initiatives.

which identifies the need for integration of social, economic, environmental and health knowledge. ${ }^{4}$ In a similar vein, the Wellcome Trust launched the Our Planet, Our Health initiative, investing $£ 75$ million over 5 years to explore the link between human health and environmental change. ${ }^{5}$ The United Nations' Sustainable Development Goals (SDGs) also emphasise the dependence of human health on the resilience of the planet's ecosystems, with specific targets that prioritise and focus global action. ${ }^{6}$

Within Australia, the 'Foundations for the future: a long-term plan for Australian ecosystem science' report, published in 2014, stated that: 'Our natural and managed ecosystems form the world we live, play and work in; the settings for our industry; and the distinctive natural heritage that characterises the Australian nation. They are the basis of our current and future prosperity, and our national well-being, ${ }^{7}$ However, a national 
Box 1 Traditional and previously underemphasised reasons for biodiversity conservation*

Traditional reasons
Useful products from nature
Medicines, food, fuel, fibre.
Mental health benefits
'Sense of place', relaxation, entertainment, inspiration.
Ethical considerations
Religious obligation to 'care for the earth'.
Emotional plight of animals in distress/species in peril.
Conserving rare species for the sake of our children.

Previously underemphasised/unrecognised reasons Essential ecosystem services

- Clean air and stable climate.

- Clean, fresh water (water security).

- Fertile soil, nutrient cycling, pollination (food security).

Mental health benefits

- Enhanced cognitive functioning with exposure to nature/green spaces.

- Psychophysiological dimensions of health.

Ethical considerations

- The right of future generations to inherit a 'healthy planet', allowing them to live a healthy life (so called 'third dimension' of medical ethics). ${ }^{52}$

Infectious disease risks

- Human infections associated with reduced biodiversity (limited 'dilution effect').

- Ecological disturbance with changed vector distributions and host/ reservoir species.

- Risks associated with human (and farmed animal) population increase, increased host $n$ density and human-animal/animal-animal interaction.

- Rise of antimicrobial resistance associated with 'environmental contamination'.

${ }^{*}$ As identified and discussed by workshop participants.

framework for a holistic Planetary Health approach has not yet been developed, nor have the health impacts of anthropogenic ecosystem changes been fully acknowledged or explored. Conservation efforts traditionally emphasised the plight of endangered animals and the loss of potentially useful natural products, but placed little emphasis on the preservation of essential ecosystem services (box 1). Although ecosystems are strained at local and global levels, unified action has been hard to coordinate. The framing of an easily understood 'value argument' is difficult, ${ }^{8}$ since incremental adverse outcomes accrue over long periods of time with multiple and poorly defined interacting factors, while the direct and opportunity costs are immediate and highly visible to the voting public. To clarify and advance the Planetary Health agenda within Australia, with particular emphasis on emerging infections and AMR, a set of open-ended questions (box 2) as well as key barriers and potential solutions were considered broadly representative group of experts from human, animal, plant, ecosystem and
Box 2 Open-ended questions addressed by lead discussants with a focus on emerging and antimicrobialresistant infections

Open-ended questions

1. What scenario keeps you awake at night?

2. What are the most important priorities for future research/policy?

3. If you had one research question and unlimited resources-what would it be?

4. What issues do you think require public consultation/involvement in decision-making?

5. In your opinion what are key barriers and potential solutions to these barriers?

policy areas box 2 at a workshop facilitated by the University of Sydney's Marie Bashir Institute for Emerging Infections and Biosecurity. Participants from different disciplinary backgrounds then took part in small group (8-10 people) discussions. Presentations and group discussions were recorded, transcribed and analysed for thematic content. The workshop was followed by a closed discussion with representatives of relevant Commonwealth and State departments, funding agencies, universities and research institutes to define a pragmatic way forward).

\section{EMERGING INFECTIOUS DISEASES}

The main themes identified were: animal reservoirs of emerging human pathogens, pathogen surveillance, mechanisms of disease emergence and disease spread by asymptomatic individuals (the so-called 'invisible man'). Tables 1 and 2 summarise relevant participant responses.

\section{Animal reservoirs}

The severe acute respiratory syndrome coronavirus (SARS-CoV) outbreak in 2003 highlighted the importance of animal reservoirs as a source of human infection. Henipavirus outbreaks, including Hendra on the Australian eastern seaboard and Nipah in Malaysia and Bangladesh, demonstrated the importance of bats as viral reservoir species and of domestic animals (horses and pigs, respectively) as amplifying hosts. ${ }^{9}$ For the Middle East respiratory syndrome coronavirus (MERS-CoV), domestic camels have been implicated as the likely amplifying hosts. ${ }^{10}$ Fortunately, serological testing of camels in Australia, which is home to the largest population of wild camels in the world, has revealed no evidence of MERS-CoV infection to date. ${ }^{11}$ Bats may also carry Ebolavirus, but its environmental reservoirs remain uncertain. ${ }^{12}$ In general, the inter-relationships between animal reservoirs and amplifying hosts, as well as the circumstances that lead to pathogen overspill or backspill between wildlife, livestock and humans are poorly characterised. ${ }^{13}$

\section{Pathogen surveillance}

In the absence of systematic pathogen surveillance in wildlife and domestic animals, human cases often act as 
Table 1 Responses to open-ended questions on EIDs

\begin{tabular}{|c|c|}
\hline Question & Responses \\
\hline $\begin{array}{l}\text { Nightmare } \\
\text { scenario }\end{array}$ & $\begin{array}{l}\text { Escape of a genetically engineered } \\
\text { highly pathogenic transmissible agent. } \\
\text { Rapid global spread of a hypervirulent } \\
\text { respiratory virus. } \\
\text { High pathogenicity virus spread by } \\
\text { ubiquitous day-biting mosquitoes. } \\
\text { High pathogenicity virus with a long } \\
\text { presymptomatic period or absence } \\
\text { of symptoms in some infectious } \\
\text { individuals ('silent man') or prolonged } \\
\text { viral shedding post recovery. }\end{array}$ \\
\hline $\begin{array}{l}\text { Priorities for } \\
\text { future research/ } \\
\text { policy }\end{array}$ & $\begin{array}{l}\text { Improving basic EID literacy } \\
\text { (professionals, politicians and public) } \\
\text { Enhanced EID surveillance and risk } \\
\text { mapping. } \\
\text { Defining the mechanisms of pathogen } \\
\text { host species 'jumping'. } \\
\text { Understanding social mobility and } \\
\text { community network structures. } \\
\text { Eco-friendly infection control } \\
\text { conscious city planning. } \\
\text { Protecting frontline staff. } \\
\text { Immunisation strategies for disease } \\
\text { prevention and outbreak response. } \\
\text { Developing rapid accurate diagnostics } \\
\text { and effective treatment. } \\
\text { Minimising adverse economic } \\
\text { impacts. } \\
\text { Advanced scenario planning to guide } \\
\text { action in an emergency. }\end{array}$ \\
\hline $\begin{array}{l}\text { Most important } \\
\text { research } \\
\text { question }\end{array}$ & $\begin{array}{l}\text { What are all the infectious agents that } \\
\text { exist in nature and their respective } \\
\text { spill-over risk to humans? } \\
\text { How to accurately value ecosystem } \\
\text { services and the societal cost } \\
\text { of human-induced ecosystem } \\
\text { disturbance? }\end{array}$ \\
\hline $\begin{array}{l}\text { Issues that } \\
\text { require public } \\
\text { consultation }\end{array}$ & $\begin{array}{l}\text { Accepted levels of public surveillance, } \\
\text { including strategies for early outbreak } \\
\text { detection and transmission chain } \\
\text { tracking. } \\
\text { Justification for escalating degrees of } \\
\text { intervention. } \\
\text { How to keep the public informed } \\
\text { during a crisis. } \\
\text { Compensation for those affected by } \\
\text { disease containment strategies. } \\
\text { Balancing individual and community } \\
\text { risks/benefits in decision-making. } \\
\text { Balancing the best interests of current } \\
\text { and future generations. }\end{array}$ \\
\hline
\end{tabular}

EID, Emerging Infectious Disease.

sentinel events that alert public health officials to a new infection of animal origin. Even when animal disease surveillance detects unusual signals, communication with human public health networks is often suboptimal, as illustrated by the West Nile virus outbreak that swept

Table 2 Key barriers and proposed solutions relating to EIDs

\begin{tabular}{ll}
\hline Key barriers & Proposed solutions \\
\hline $\begin{array}{l}\text { Rapid loss of } \\
\text { interest after a } \\
\text { crisis is resolved }\end{array}$ & $\begin{array}{l}\text { Health security to be given standing } \\
\text { priority. }\end{array}$ \\
& $\begin{array}{l}\text { Ensure that the lessons learnt from } \\
\text { EID crises/scares are reviewed and } \\
\text { appropriate actions implemented; } \\
\text { create national expert body to } \\
\text { facilitate this. }\end{array}$ \\
& $\begin{array}{l}\text { Continuous education of politicians } \\
\text { and the general public. }\end{array}$ \\
Politicians hearing & $\begin{array}{l}\text { Scientists to consolidate messaging } \\
\text { (national expert body). } \\
\text { many different } \\
\text { voices }\end{array}$ \\
& $\begin{array}{l}\text { Package scientific findings into } \\
\text { effective messages. }\end{array}$ \\
\hline
\end{tabular}

$\begin{array}{ll}\begin{array}{l}\text { Communication of } \\ \text { uncertainty }\end{array} & \begin{array}{l}\text { Work with politicians and the public } \\ \text { to view EID preparation and scenario } \\ \text { planning as an insurance policy. } \\ \end{array} \\ & \begin{array}{l}\text { Refine scenario planning and } \\ \text { improve preparedness at all } \\ \text { levels (public health officials, } \\ \text { researchers, professional groups and } \\ \text { policymakers). }\end{array} \\ & \text { Work with the public and the media } \\ & \text { to optimise communication. } \\ \text { Delay in getting } & \text { Consider important research } \\ \text { research } & \text { questions (national expert body). } \\ \text { proposals } & \text { Prepare generic research proposals } \\ \text { approved during } & \text { in advance. } \\ \text { an outbreak } & \text { Fast-track ethics approval processes } \\ & \text { during epidemic outbreaks. }\end{array}$

\section{Weak EID}

surveillance and response systems within the Asia Pacific region

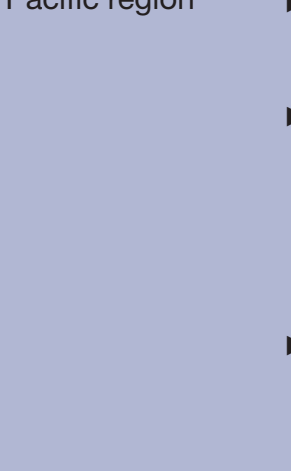

Separation of animal and human disease data, research and policy
- Comprehensive assessment of regional IHR-2005 implementation.

- Improved laboratory/diagnostic capacity and reporting structures.

- Increased domestic funding, as well as international aid, with a specific focus on regional health security.

- Expand IHR-2005 to include focus on livestock and wildlife disease surveillance or integrate with complimentary processes such as the OIE's Evaluation of Performance of Veterinary Services.

- Remunerate farmers for losses incurred as a result of disease detection to secure their cooperation in surveillance efforts.

- Identify overlapping issues in human and animal health; understand and respect each other's perspectives.

- Funding agencies to encourage and support joint research opportunities that links human, animal and environmental health.

- Create national oversight body containing human, animal and environmental health experts. 
Table 2 Continued

\begin{tabular}{|c|c|}
\hline Key barriers & Proposed solutions \\
\hline $\begin{array}{l}\text { Separate } \\
\text { government } \\
\text { structures for } \\
\text { human and animal } \\
\text { public health }\end{array}$ & $\begin{array}{l}\text { Encourage cross-discipline } \\
\text { collaboration at Commonwealth } \\
\text { and State levels; regular meetings } \\
\text { between human and animal public } \\
\text { health officials (including wildlife). } \\
\text { Increase cross-ministerial interaction } \\
\text { at Cabinet and senior government } \\
\text { official level. }\end{array}$ \\
\hline $\begin{array}{l}\text { Restrictive } \\
\text { discipline focus } \\
\text { in academic } \\
\text { institutions }\end{array}$ & $\begin{array}{l}\text { Broaden undergraduate exposure to } \\
\text { the 'natural sciences'. } \\
\text { Encourage multidisciplinary } \\
\text { perspectives and complex systems } \\
\text { awareness at under and post- } \\
\text { graduate levels, for example, joint } \\
\text { One/Eco/Planetary Health training } \\
\text { between medical and veterinary } \\
\text { schools; Master degrees in One/Eco/ } \\
\text { Planetary Health, Health Security or } \\
\text { Complex Systems. }\end{array}$ \\
\hline
\end{tabular}

EID, Emerging Infectious Disease; IHR, International Health Regulations; OIE, World Organisation of Animal Health.

across the USA. ${ }^{14}$ The risk of infections spreading from wildlife reservoirs into human populations is exacerbated by the expansion of agriculture and mining into natural environments, road infrastructure, deforestation, subsistence hunting and co-location of wild and domestic animals in so-called wet markets. Strategically, targeted surveillance of the environment, domestic and wild animals, infection vectors and vulnerable human populations will facilitate early detection and better control of disease emergence risk. ${ }^{15}$

The importance of pathogen surveillance has been emphasised by both the Ebola Interim Assessment Panel chaired by Dame Barbara Stocking ${ }^{16}$ and the Independent Panel on the Global Response to Ebola chaired by Professor Peter Piot. ${ }^{17}$ The Stocking report recognised poor implementation of International Health Regulations (IHR), which were approved by the World Health Assembly in 2005, as well as the need for global solidarity to build local capacity, which has been incorporated in target 3.d of the SDGs: 'Strengthen the capacity of all countries, in particular developing countries, for early warning, risk reduction and management of national and global health risks'. IHR implementation requires strong government commitment to establish and maintain public health laboratory and service provider capacity. The US committed US\$1 billion towards the Global Health Security Agenda, ${ }^{18}$ while the UK created a $£ 1$ billion fund in partnership with the Bill and Melinda Gates Foundation to tackle malaria and other infectious diseases. ${ }^{19}$ The Australian government committed $\$$ A300 million over 5 years 2017-2022 to the Indo-Pacific Centre for Health Security, ${ }^{20}$ assisting core capacity strengthening and complementing WHO's regional strategy for emerging diseases and public health emergencies in the Asia-Pacific (Asia Pacific Strategy for Emerging Diseases; APSED III 2017). ${ }^{21}$

\section{Mechanisms of disease emergence}

The synthesis of data on the ecology and evolutionary biology of various organisms provide enhanced understanding of pathogen emergence, but information on the social mechanisms that underpin disease outbreaks and persistence remains rudimentary. For example, the reasons for increasing rates of human non-typhoidal salmonellosis in Australia (noted at the workshop), at a time when rates were falling in most comparable countries, were poorly understood. Integration of food, animal and human surveillance data could provide the insight needed to improve control of these infections. The impact of climate change, particularly on water and vector-borne diseases, was highlighted as a key concern. Viruses spread by Aedes aegypti and A. albopictus mosquitoes (Zika, dengue and chikungunya) pose a significant risk to global health. So far, Australia has successfully restricted these mosquito populations, but the likelihood of their permanent establishment will increase with climate change. ${ }^{22}$ Mosquito surveillance in Australia is undertaken on a state-by-state basis with coordination by the National Arbovirus and Malaria Advisory Committee. More comprehensive and better standardised surveillance programmes will facilitate accurate mapping of mosquito populations and better tracking of endemic and imported viruses.

\section{The 'invisible man'}

Presymptomatic or asymptomatic individuals can unwittingly spread infection. Salient examples include the spread of HIV from asymptomatically infected individuals, the 48 hours presymptomatic period during which patients with influenza are infectious and unrecognised colonisation with multidrug-resistant organisms. Outbreak control strategies usually depend on syndromic diagnosis and cluster identification to guide intervention strategies. When outbreaks are fuelled by unrecognised human vectors, the importance of routine infection control precautions becomes evident and pre-emptive control measures such as quarantine of high-risk individuals or large-scale social distancing may be appropriate. Such measures are difficult to implement. Risk assessment and modelling to predict the most likely eventualities in advance and develop realistic scenarios to aid public health response preparedness are important to guide mitigation strategies.

\section{Key barriers and proposed solutions}

Strengthening of public health systems, especially in low-income and middle-income countries, is essential to achieve core IHR capacities. The Australian Government's Health for Development Strategy 2015-2020 articulated most of the important elements required for a comprehensive regional response, ${ }^{23}$ but Australia's 
international aid budget has declined to its lowest level in many decades; falling well short of international targets. ${ }^{24}$ Effective implementation of the joint external evaluation process in the Asia-Pacific region has provided a valuable overview of country-level preparedness, but it needs to be combined with the World Organisation of Animal Health (OIE) Evaluation of Performance of Veterinary Services assessment to improve One Health surveillance, while ongoing monitoring is essential to ensure that identified capacity gaps are addressed and best practices shared. ${ }^{24} 25$

It is predictable that EIDs will escalate in frequency. Although much effort has been expended in developing pandemic preparedness policies, recent experiences with SARS and MERS-CoV demonstrated that even the most advanced medical systems require continued vigilance linked to careful scenario response planning. ${ }^{25-27}$ Epidemic outbreaks, or even the perceived threat of an epidemic, usually lead to a flurry of activity, but lessons learnt and interim policies developed are rarely consolidated during interepidemic periods. Successful policy implementation requires an expert panel that represents all relevant disciplines, to work with the Commonwealth Office of Health Protection to draft national guidelines and monitor implementation of actions to reduce the likelihood and negative impact of EIDs. It could also oversee the drafting of generic research proposals to test interventions and generate enhanced insight during epidemic outbreaks.

Methodologies for better decision-making during emergencies require refinement. ${ }^{28-30}$ The Rockefeller-Lancet commission identified three important strategies, adopting a threshold approach, scenario planning and resilience thinking. These require pre-emptive scoping of relevant risks, as well as possible scenarios and outcomes associated with identified courses of action. Effective public communication in times of uncertainty poses a major challenge. The Australian media were more measured than media outlets in the USA during the 2014 Ebola virus outbreak, but news reports still generated considerable public anxiety. Detailed scenario planning will help to identify priority actions and communication strategies to reassure the public that the situation is under control and that perceived risks are manageable. Optimal communication will require close liaison between researchers, public health officials (for human, animal and environmental health), policymakers and the media.

Within Australia, there is no formal framework within academic institutions or government to facilitate and support cross-disciplinary collaboration, although the National Framework for Communicable Disease Control does encourage a One Health approach to pandemic preparedness. ${ }^{31}$ Increased AMR awareness has been encouraging ${ }^{3233}$ but like climate change progress is slow, given the multiple vested interests and differences in risk/benefit perception. Much can also be learnt from the roadmap developed by the US Centers for Disease Control and Prevention (CDC) to assist One Health operationalisation. ${ }^{34}$ The Australian National Antimicrobial Resistance Strategy 2015-2019, jointly developed by the Departments of Health and Agriculture and Water Resources, represents an example of how these silos can be linked, ${ }^{35}$ but implementation remains challenging.

\section{ANTIMICROBIAL RESISTANCE (AMR)}

Table 3 summarises participant responses to open-ended questions focused on AMR. The main discussion themes included antimicrobial use in production animals, AMR in companion animals, antimicrobial stewardship and public education. Table 4 provides an overview of key barriers and potential solutions identified.

\section{Antimicrobial use in production and companion animals}

The ecological effects of antimicrobial selection pressure, including its effects on the human and animal microbiome, are poorly understood. Antimicrobial use in production animals has been restricted in Australia following the recommendations of the Swann report. ${ }^{36}$ When avoparcin use in feedlot cattle was shown to increase the prevalence of Enterococcus faecium resistance to vancomycin (a glycopeptide antibiotic used for the treatment of human infections), ${ }^{37}$ it was voluntarily withdrawn from the Australian market. Fluoroquinolones were never approved for use in production animals in Australia, which probably explains the low levels of fluoroquinolone resistance observed in Campylobacter, Salmonella and Escherichia species compared with other countries where agricultural use is unrestricted. ${ }^{38}{ }^{39}$ Globally, the pork and chicken industries are the biggest users of antimicrobials. ${ }^{40}$ Recent descriptions of highly resistant bacteria found on chicken and swine farms in China, linked to outbreaks of human infection with bacteria containing similar plasmid-mediated resistance, offer a stark example of the health risks associated with unregulated antimicrobial use in production animals. ${ }^{4142}$ However, it was acknowledged that the responsible use of antimicrobials to address concerns about food security and animal welfare require careful consideration.

Companion animals are important to Australians; $63 \%$ of households own pets and the pet industry contributes nearly US $\$ 4.75$ billion to the Australian economy, employing 45000 people. ${ }^{43}$ The health benefits of pet ownership are estimated to save the healthcare system approximately US $\$ 2.25$ billion per year. ${ }^{44}$ Despite the intensity of interaction, there has been surprisingly little research into the transmission of AMR between pathogens of humans and their pets. A better understanding of antimicrobial use in companion animals is needed, since there is no regulatory guidance and pets fall outside the agriculture and health portfolios.

\section{Antimicrobial stewardship and public education}

Australian doctors prescribe more than twice the amount (in defined daily doses per 1000 population per day) of antibiotics compared with their counterparts in the 
Table 3 Responses to open-ended questions on antimicrobial resistance (AMR)

\begin{tabular}{|c|c|}
\hline Question & Responses \\
\hline Nightmare scenario & $\begin{array}{l}\text { Global spread and dominance of totally antimicrobial resistant pathogens - } \\
\text { returning to the preantibiotic era }\end{array}$ \\
\hline Most important research question & $\begin{array}{l}\text { Are there effective treatment strategies that will reduce selective pressure and } \\
\text { on-going evolutionary 'escape', such as increasing bacterial susceptibility } \\
\text { to immune attack or reducing the risk/impact of invasive bacterial infection } \\
\text { only? } \\
\text { What are the key characteristics of a healthy microbiome and the short and } \\
\text { long term impacts of antimicrobial induced changes? }\end{array}$ \\
\hline Issues that require public consultation & $\begin{array}{l}\text { Restricting antimicrobial access to reduce inappropriate use, for example } \\
\text { stronger regulation or increases in price } \\
\text { How best to educate the general public and prescribers about the dangers } \\
\text { (personal and environmental) of inappropriate antimicrobial use. } \\
\text { Balancing animal and human welfare considerations. } \\
\text { Balancing distributive justice and community versus individual cost-benefit. }\end{array}$ \\
\hline
\end{tabular}

AMR, antimicrobial resistance.

Netherlands. ${ }^{45}$ At least $30 \%$ of prescriptions are judged by experts to be clinically inappropriate, inadequate or unnecessary. Litigation risk aversion, diagnostic uncertainty, time pressure and perceived patient demand are among the reasons why doctors overprescribe antibiotics. ${ }^{46}$ Evidence of previously unrecognised harm related to impacts on the human microbiome, as well as the social and ecological harm from AMR, should inform development of novel strategies to optimise antimicrobial use. A public policy research agenda, informed by social scientists and psychologists, should explore how best to reform policy settings, devise appropriate incentives and disincentives, develop innovative public and professional education programmes and use social media to improve public understanding and influence responsible regulation expectations. Both the general public and professional groups require an enhanced appreciation of basic infection control principles.

\section{Key barriers and solutions proposed}

Based on scenarios of increasing AMR prevalence for six pathogens, it has been estimated that by 2050, 10 million lives per year and 100 trillion USD of economic output may be lost due to AMR infections. ${ }^{33}$ A divisive debate has focused on the relative impacts of human versus animal or agricultural use of antimicrobials, but constructive collaboration is essential to elucidate and mitigate the key drivers of AMR. A major advance in promoting a One/Eco Health approach to AMR in Australia was achieved through the joint support of the Australian Chief Medical and Veterinary Officers to develop and implement a National AMR Strategy. This is the first joint ministerial initiative between the Australian Government Departments of Health and of Agriculture and Water Resources.

The WHO's Antimicrobial Resistance: Global Report on Surveillance (2014) identified a policy package with broad goals that included strengthened surveillance and laboratory capacity. ${ }^{47}$ However, without adequate funding and accountability measures, such farsighted policies will continue to fall short, especially in the Asia-Pacific region where antimicrobial use is essentially unregulated and strong financial incentives exist to retain the status quo. The WHO Western Pacific Region's Action Agenda is a step towards tackling these problems, but the agenda includes no plans for 
Table 4 Key barriers and proposed solutions relating to AMR and antimicrobial use

\begin{tabular}{|c|c|}
\hline Key barriers & Proposed solutions \\
\hline $\begin{array}{l}\text { Potentially } \\
\text { divisive } \\
\text { arguments of } \\
\text { human versus } \\
\text { animal use }\end{array}$ & $\begin{array}{l}\text { Develop joint National AMR Strategy } \\
\text { with input from all sectors. } \\
\text { Restrict use of antimicrobials in } \\
\text { agriculture to those with limited cross- } \\
\text { over resistance. } \\
\text { Companion animals to have the same } \\
\text { access as humans. }\end{array}$ \\
\hline $\begin{array}{l}\text { Companion } \\
\text { animals are } \\
\text { excluded from } \\
\text { agriculture and } \\
\text { health portfolios }\end{array}$ & $\begin{array}{l}\text { Provide a 'home' for companion animal } \\
\text { health within the Commonwealth } \\
\text { government structures. } \\
\text { Provide AMR prescribing guidelines } \\
\text { for companion animals, including } \\
\text { antimicrobial stewardship programmes } \\
\text { and improved infection control. }\end{array}$ \\
\hline $\begin{array}{l}\text { Problem of } \\
\text { attribution }\end{array}$ & $\begin{array}{l}\text { Elucidate sources of AMR organisms } \\
\text { including in humans (hospital vs } \\
\text { community), animals (companion vs } \\
\text { livestock vs wildlife) and environment } \\
\text { (eg, water or soil). } \\
\text { Provide research funding for negative } \\
\text { impacts on ecosystems and animal } \\
\text { health, irrespective of human health. }\end{array}$ \\
\hline $\begin{array}{l}\text { Limited } \\
\text { funding for } \\
\text { multidisciplinary } \\
\text { research }\end{array}$ & $\begin{array}{l}\text { Provide funding avenues for } \\
\text { multidisciplinary research, especially } \\
\text { those combining human, animal and } \\
\text { environmental health. } \\
\text { Consider dedicated funding provision } \\
\text { from the new MRFF. }\end{array}$ \\
\hline
\end{tabular}

Global/regional Focus on AMR (including growing drug rather than a national problem resistance in tuberculosis and malaria) as part of the DFAT regional Health Security agenda.

- Strengthened international/regional AMR legislation, improved governance and stewardship should be key international development outcomes.

- WHO to develop better global AMR accountability measures.

Spread of mobile Understand and monitor the mobile resistance elements genetic pool, including spread by wild animals and bird populations.

- Support regional/global strategies.

$\begin{array}{ll}\begin{array}{l}\text { Antimicrobials } \\ \text { are cheap and } \\ \text { easily available }\end{array} & \begin{array}{l}\text { Restrict prescribing of certain } \\ \text { antimicrobials. }\end{array} \\ & \begin{array}{l}\text { Consider deferred prescribing if } \\ \text { uncertain diagnosis and not acutely ill. } \\ \text { Consider ways to make antimicrobials } \\ \text { more expensive, }{ }^{*} \text { without restricting } \\ \text { access for people who need them. }\end{array} \\ \begin{array}{l}\text { Unnecessary } \\ \text { supply and }\end{array} & \begin{array}{l}\text { Educate children and the public about } \\ \text { perceived public } \\ \text { demand }\end{array} \\ & \text { Institute effective antimicrobial } \\ & \text { stewardship programmes. } \\ & \text { Make institutional antimicrobial use } \\ & \text { and drug resistance profiles public. }\end{array}$

Continued
Table 4 Continued

\begin{tabular}{|c|c|}
\hline Key barriers & Proposed solutions \\
\hline $\begin{array}{l}\text { Inadequate } \\
\text { infection control } \\
\text { leading to } \\
\text { transmission of } \\
\text { AMR organisms }\end{array}$ & $\begin{array}{l}\text { Improved sanitation and environmental } \\
\text { hygiene. } \\
\text { Better infection control practice } \\
\text { in hospitals and other healthcare } \\
\text { settings. } \\
\text { Better infection control awareness in } \\
\text { the general community and targeted } \\
\text { measures in congregate settings. }\end{array}$ \\
\hline $\begin{array}{l}\text { Poor } \\
\text { communication } \\
\text { and } \\
\text { collaboration } \\
\text { between states }\end{array}$ & $\begin{array}{l}\text { Standard approach taken across } \\
\text { states and territories. } \\
\text { Standardise susceptibility testing, } \\
\text { surveillance, governance and } \\
\text { antimicrobial stewardship procedures. } \\
\text { Consider routine reporting of drug- } \\
\text { resistant infections as good clinical } \\
\text { practice (laboratory accreditation } \\
\text { requirement). }\end{array}$ \\
\hline $\begin{array}{l}\text { Antimicrobial } \\
\text { development } \\
\text { deliver poor } \\
\text { return on } \\
\text { investment }\end{array}$ & $\begin{array}{l}\text { Recognise the failure of standard } \\
\text { market mechanisms } \\
\text { Advocate for the development of } \\
\text { alternative funding models, including } \\
\text { consideration of public-private } \\
\text { partnerships or a health insurance } \\
\text { model. } \\
\text { Develop less expensive adaptive trial } \\
\text { strategies. }\end{array}$ \\
\hline
\end{tabular}

*There was concern that an imposed AMR tax may limit or distort appropriate use in people who really need antibiotics.

AMR, antimicrobial resistance; DFAT, Australian Department of Foreign Affairs and Trade; MRFF, Medical Research Futures fund.

effective stewardship. ${ }^{48}$ Lack of funding for cross-disciplinary research was identified as a significant barrier; participants believed that this was exacerbated by the separation of the two major Australian public research funding bodies-the National Health and Medical Research Council (medical) and the Australian Research Council (non-medical). Breaking down traditional medical, veterinary and biological research silos is crucial, with dedicated funding to support cross-disciplinary initiatives.

Few new antimicrobials have been developed in recent years, as antimicrobials do not deliver attractive returns on investment. ${ }^{33}$ Private-public partnerships have been used with success to develop vaccines for neglected diseases, ${ }^{49}$ but this requires generous philanthropic support. New economic models should reward antimicrobial discovery (or novel non-antibiotic approaches to reducing AMR) as a public good, delinking the return on investment from the volume of sales. The Association of British Pharmaceutical Industries Antibiotics Network has suggested an insurance-based model that guarantees an annual license fee, providing a more predictable return on investment. ${ }^{50}$ While the development of new antimicrobial drugs is important in the short term, history has shown that resistance will 
develop in response to selection pressure and spread without appropriate infection control measures. Alternative therapeutic strategies, such as bacteriophage treatment may be successful if linked to rapid and accurate pathogen identification. Attempts to reduce selection pressure fuelled by indiscriminate microbial killing, includes highly targeted bacteriophage-based approaches, modification of disease causing microbes to make them more susceptible to immune attack and developing strategies that prevent or selectively treat invasive disease only. Rapid point-of-care tests that differentiate viral and bacterial infections, and provide antimicrobial susceptibility profiles, would assist more targeted use of conventional antibiotics.

\section{CONCLUSION}

The challenge posed by EIDs and AMR requires careful consideration of effective mechanisms for prevention and response. Table 5 summarises the processes and activities identified for a coordinated Australian response to the threat of EIDs, supported by the recently released National Action Plan for Health Security. ${ }^{51}$ While the National AMR Strategy ${ }^{35}$ emphasises

Table 5 Processes and activities proposed to move the National Emerging Infectious Diseases (EID) agenda forward in Australia, using an ambitious Planetary Health approach

EID

\section{Process}

Develop a National EID strategy*

\section{Activities/steps}

- Follow-up meeting jointly led by the Departments of Health and Agriculture and Water Resources, involving academia, the Department of Foreign Affairs and Trade (DFAT) and the Commonwealth Scientific and Industrial Research Organisation (CSIRO).

- Political advocacy to improve awareness, create a sense of urgency and ensure cross-ministerial support.

- Establish a national EID expert committee, including leaders from recently established Centres of Research Excellence in EIDs, Communicable Disease Network, Australia, OzFoodNet (www.ozfoodnet.gov.au) and relevant discipline expertise from outside of medicine.

- Convene an expert panel to draft a Road Map for a national response to the threat of Emerging Infectious Diseases (including human, animal and plant diseases of major consequence)coordinated nationally and led by the Departments of Health and Agriculture and Water Resources.

- Develop a National Strategy* that links closely with the 'Responding to the threat of antimicrobial resistance' strategy 2015-2019.

- Develop and monitor national EID surveillance, preparedness and response plans.

- Develop frameworks for the optimal and ethical application of new technologies, such as social network surveillance and advanced pathogen genomics.

Provide leadership within the Asia Pacific region and link with international efforts

Strengthen linkages with and support of regional WHO offices (Western Pacific and Southeast Asia), especially the 'Health Security and Emergencies' and 'communicable diseases' sections and other regional mechanisms and forums, including the South Pacific Commission, the East Asia Summit and the Asia Pacific Economic Cooperation, as well as global initiatives such as Global Health Security Agenda and the Development Banks.

- Scope country-level implementation of IHR-2005.

- Encourage adequate funding of DFAT's Regional Health Security strategy.

- Link with One/Eco/Planetary health communities in other countries, encourage a 'united front' and support international efforts

*This was recently completed, ${ }^{51}$ but many of the core elements remain to be executed. 
the need for a coordinated One Health approach, implementation within existing government structures remains challenging without significant internal reform. Public education should also target politicians and key decision-makers, since implementation requires strong political will and requisite funding.

\section{Author affiliations}

${ }^{1}$ Marie Bashir Institute for Infectious Diseases and Biosecurity (MBI), The University of Sydney, Sydney, New South Wales, Australia

${ }^{2}$ School of Public Health, The University of Sydney, Sydney, New South Wales, Australia

${ }^{3}$ Department of Agriculture and Water Resources, Canberra, Australian Capital Territory, Australia

${ }^{4}$ Australian Centre for International Agricultural Research, Canberra, Australian Capital Territory, Australia

${ }^{5}$ Research Policy and Translation, National Health and Medical Research Council (NHMRC), Canberra, Australian Capital Territory, Australia

${ }^{6}$ Department of Health, Office of Health Protection, Canberra, Australian Capital Territory, Australia

Acknowledgements The authors would like to thank Kerri Anton for developing and designing the layout and structure of the workshop, and Christine Aitken for event organisation. We also thank participants from all the different sectors that took part, including Martin Kirk (National Centre for Epidemiology \& Population Health at the Australian National University, Canberra, Australia), Elizabeth Harry (The ithree institute, The University of Technology Sydney, Australia) and Ben Howden (Microbiological Diagnostic Unit Public Health Laboratory, The Doherty Institute for Infection and Immunity, Melbourne, Australia) who contributed to the closed group discussion. The meeting was supported by the University of Sydney

Contributors BM and GH-C conceptualised the manuscript and led the workshop. All authors contributed to the workshop and assisted with the development of the content and review of the manuscript.

Funding The authors have not declared a specific grant for this research from any funding agency in the public, commercial or not-for-profit sectors.

Competing interests None declared.

Patient consent for publication Not required.

Provenance and peer review Not commissioned; internally peer reviewed.

Data availability statement № additional data are available.

Open access This is an open access article distributed in accordance with the Creative Commons Attribution Non Commercial (CC BY-NC 4.0) license, which permits others to distribute, remix, adapt, build upon this work non-commercially, and license their derivative works on different terms, provided the original work is properly cited, appropriate credit is given, any changes made indicated, and the use is non-commercial. See: http://creativecommons.org/licenses/by-nc/4.0/.

\section{REFERENCES}

1. World Economic Forum. Global Risks 2015 [Internet]. Geneva: World Economic Forum. Available: http://reports.weforum.org/global-risks2015/

2. Marais B, Crawford J, Iredell J, et al. One world, one health: beyond the millennium development goals. Lancet 2012;380:805-6

3. FAO, OIE, WHO, UN System Influenza Coordination, UNICEF, The World Bank. Contributing to One World, One Health [Internet]. fao. org. Available: http://www.fao.org/docrep/011/aj137e/aj137e00.HTM

4. Whitmee S, Haines A, Beyrer C, et al. Safeguarding human health in the Anthropocene epoch: report of the Rockefeller Foundation-Lancet Commission on planetary health. Lancet 2015;386:1973-2028.

5. Devi S. Wellcome trust launches our planet, our health Initiative. Lancet 2015;386.

6. United Nations. Sustainable Development Goals [Internet]. sustaina bledevelopment.un.org, 2015. Available: https://sustainabledevel opment.un.org/?menu=1300 [Accessed cited 2016 May]

7. Andersen A, Beringer J, Bull CM, et al. Foundations for the future: a long-term plan for Australian ecosystem science. Austral Ecol 2014;39:739-48.
8. Horton R, Beaglehole R, Bonita R, et al. From public to planetary health: a manifesto. The Lancet 2014;383.

9. Plowright RK, Eby P, Hudson PJ, et al. Ecological dynamics of emerging bat virus spillover. Proc Biol Sci 2015;282:20142124.

10. Corman VM, Jores J, Meyer B, et al. Antibodies against MERS coronavirus in dromedary camels, Kenya, 1992-2013. Emerg Infect Dis 2014;20:1319-22.

11. Crameri G, Durr PA, Barr J, et al. Absence of MERS-CoV antibodies in feral camels in Australia: implications for the pathogen's origin and spread. One Health 2015;1:76-82.

12. Reed PE, Mulangu S, Cameron KN, et al. A new approach for monitoring ebolavirus in wild great apes. PLoS Negl Trop Dis 2014;8:e3143.

13. Daszak P, Cunningham AA, Hyatt AD. Emerging infectious diseases of wildlife--threats to biodiversity and human health. Science 2000;287:443-9.

14. O'Hara JA. West Nile virus: success of public health response underlines failure of the system. J Urban Health 2001;78:392-5.

15. Karesh WB, Dobson A, Lloyd-Smith JO, et al. Ecology of zoonoses: natural and unnatural histories. Lancet 2012;380:1936-45.

16. WHO. Stocking B. Final report of the Ebola interim assessment panel, 2015. Available: http://www.who.int/entity/csr/resources/ publications/ebola/ebola-panel-report/en/index.html [Accessed 16 June 2018]

17. Moon S, Sridhar D, Pate MA, et al. Will Ebola change the game? ten essential reforms before the next pandemic. the report of the Harvard-LSHTM independent panel on the global response to Ebola. Lancet 2015;386:2204-21.

18. Office of the Press Secretary. FACT SHEET: The Global Health Security Agenda [Internet]. whitehouse.gov, 2015. Available: https:// www.whitehouse.gov/the-press-office/2015/07/28/fact-sheet-globalhealth-security-agenda

19. HM Treasury, Department for International Development. Chancellor George Osborne and Bill Gates to join forces to end malaria [Internet]. gov.uk, 2015. Available: https://www.gov.uk/government/ news/chancellor-george-osborne-and-bill-gates-to-join-forces-toend-malaria [Accessed cited 2015 Dec].

20. Indo-Pacific Centre for Health Security announcement. Available: https://foreignminister.gov.au/speeches/Pages/2017/jb_sp_171008. aspx?w=tb1CaGpkPX\%2FISOK\%2Bg9ZKEg\%3D\%3D [Accessed 16 June 2018].

21. WHO. Asia Pacific strategy for emerging diseases and public health emergencies (APSED III): advancing implementation of the international health regulations, 2005. Available: http://iris.wpro. who.int/bitstream/handle/10665.1/13654/9789290618171-eng.pdf [Accessed 16 June 2018].

22. Russell RC, Currie BJ, Lindsay MD, et al. Dengue and climate change in Australia: predictions for the future should incorporate knowledge from the past. Med J Aust 2009;190:265-8.

23. Health for Development Strategy 2015-2020. Australian department of foreign Affairs and trade. Available: https://dfat.gov.au/about-us/ publications/Documents/health-for-development-strategy-20152020.PDF [Accessed 16 June 2018].

24. Pearson LB. A New Strategy for Global Development [Internet]. Koffler S, editor. UNESCO, 1970. Available: http://unesdoc.unesco. org/images/0005/000567/056743eo.pdf

25. Marais BJ, Williams S, Li A, et al. Improving emergency preparedness and response in the Asia-Pacific. BMJ Glob Health 2019;4:e001271.

26. Svoboda T, Henry B, Shulman L, et al. Public health measures to control the spread of the severe acute respiratory syndrome during the outbreak in Toronto. N Engl J Med 2004;350:2352-61.

27. Cho SY, Kang J-M, Ha YE, et al. MERS-CoV outbreak following a single patient exposure in an emergency room in South Korea: an epidemiological outbreak study. The Lancet 2016;388:994-1001.

28. Starmer C. Developments in non-expected utility theory: the hunt for a descriptive theory of choice under risk. J Econ Lit 2000;38:332-82.

29. Chichilnisky G. An axiomatic approach to choice under uncertainty with catastrophic risks. Resour Energy Econ 2000;22:221-31.

30. Polasky S, Carpenter SR, Folke C, et al. Decision-making under great uncertainty: environmental management in an era of global change. Trends Ecol Evol 2011;26:398-404.

31. Commonwealth of Australia. National Framework for Communicable Disease Control [Internet]. Williams S, editor. health.gov.au, 2014. Available: http://www.health.gov.au/internet/ main/publishing.nsf/Content/ohp-nat-frame-communic-diseasecontrol.htm

32. Department of Health. UK Five Year Antimicrobial Resistance Strategy [Internet]. HM Government, 2013. Available: https://www. gov.uk/government/uploads/system/uploads/attachment_data/file/ 244058/20130902_UK_5_year_AMR_strategy.pdf 
33. O'Neill J. Tackling Drug-Resistant Infections Globally [Internet]. HM Government, 2016. Available: http://amr-review.org/sites/ default/files/160525_Final\%20paper_with\%20cover.pdf

34. Centers for Disease Control and Prevention (CDC). Operationalizing "One Health": A Policy Perspective [Internet]. cdc.gov, 2011. Available: https://www.cdc.gov/onehealth/pdfs/ atlanta/meeting-overview.pdf

35. Commonwealth of Australia. Responding to the Threat of Antimicrobial Resistance [Internet]. Available: http://www.health. gov.au/internet/main/publishing.nsf/Content/ohp-amr.htm

36. Swann MM, Baxter KL, Field HI. Report of the Joint Committee on the use of antibiotics in animal husbandry and veterinary medicine. London: HM Stationery Office, 1969.

37. Bager F, Madsen M, Christensen J, et al. Avoparcin used as a growth promoter is associated with the occurrence of vancomycin-resistant Enterococcus faecium on Danish poultry and pig farms. Prev Vet Med 1997;31:95-112.

38. Unicomb LE, Ferguson J, Stafford RJ, et al. Low-level fluoroquinolone resistance among Campylobacter jejuni isolates in Australia. Clin Infect Dis 2006;42:1368-74.

39. Cheng AC, Turnidge J, Collignon P, et al. Control of fluoroquinolone resistance through successful regulation, Australia. Emerg Infect Dis 2012;18:1453-60.

40. Van Boeckel TP, Brower C, Gilbert M, et al. Global trends in antimicrobial use in food animals. Proc Natl Acad Sci U S A 2015:112:5649-54.

41. Liu Y-Y, Wang Y, Walsh TR, et al. Emergence of plasmid-mediated colistin resistance mechanism MCR-1 in animals and human beings in China: a microbiological and molecular biological study. Lancet Infect Dis 2016;16:161-8.

42. Wang $Y$, Dong $Y$, Deng $F$, et al. Species shift and multidrug resistance of Campylobacter from chicken and swine, China, 2008-14. J Antimicrob Chemother 2016;71:666-9.
43. Australian Companion Animal Council. Australians and their Pets [Internet]. acac.org.au. Available: http://www.acac.org.au/pdf/ PetFactBook_June-6.pdf

44. Headey B. Health benefits and health cost savings due to pets: preliminary estimates from an Australian national survey. Soc Indic Res 1999;47:233-43.

45. Australian Commission on Safety and Quality in Health Care. Antimicrobial Prescribing Practice in Australia [Internet]. Commonwealth of Australia, 2014. Available: http://www. safetyandquality.gov.au/publications/antimicrobial-prescribingpractice-in-australia-results-of-the-2013-national-antimicrobialprescribing-survey-november-2014/

46. Broom A, Broom J, Kirby E. Cultures of resistance? A Bourdieusian analysis of doctors' antibiotic prescribing. Soc Sci Med 2014;110:81-8.

47. World Health Organization. Antimicrobial resistance: global report on surveillance 2014. WHO. World Health organization, 2014

48. WHO Western Pacific Region. Action Agenda for Antimicrobial Resistance in the Western Pacific Region [Internet]. who.org, 2015. Available: http://www.wpro.who.int/entity/drug_resistance/ documents/action_agenda.pdf

49. Gavi. Gavi's partnership model [Internet]. gavi.org, 2016. Available: http://www.gavi.org/about/gavis-partnership-model/ [Accessed cited 2016 Feb]

50. Association of the British Pharmaceutical Industry. Antimicrobial resistance. house of commons science and technology select Committee, editor 2014:1-5.

51. Australian Government. Australia's National Action Plan for health security 2019-2023. Available: http://www.health.gov.au/internet/ main/publishing.nsf/Content/054D7F36DA7F8F72CA2581A8 001278EB/\$File/Aust-Nat-Action-Plan-Health-Security-2019-2023. pdf

52. Marais BJ. Ethics; the third dimension. Arch Dis Child 2004:89:1077-8. 